Article

\title{
Mobility Infrastructures in Cities and Climate Change: An Analysis Through the Superblocks in Barcelona
}

\author{
Iván López ${ }^{1, *}$, Jordi Ortega ${ }^{2}$ and Mercedes Pardo ${ }^{3}$ \\ 1 Department of Psychology and Sociology, University of Zaragoza, 50009 Zaragoza, Spain \\ 2 Department of Material Science and Engineering, Polytechnic University of Catalonia, 08019 Barcelona, \\ Spain; jordiortega@hotmail.com \\ 3 Department of Social Analysis, University Carlos III of Madrid, 28903 Getafe, Spain; \\ mercedes.pardo@uc3m.es \\ * Correspondence: ivalopez@unizar.es
}

Received: 2 April 2020; Accepted: 17 April 2020; Published: 20 April 2020

check for updates

\begin{abstract}
Cities are key actors in the fight against climate change since they are major sources of greenhouse gas (GHG) emissions while at the same time they experience the negative impact of this phenomenon. Mitigating and adapting to climate change requires fundamental changes in urbanism and city automobile traffic. Superblocks, a grid of blocks and basic roads forming a polygon, approximately 400 by $400 \mathrm{~m}$, are one of the instruments for such changes. These type of city Superblocks represent a new model of mobility that restructures the typical urban road network, thereby substantially reducing automobile traffic, and accordingly GHG emissions, while increasing green space in the city and improving the health and quality of life of its inhabitants. Furthermore, the Superblocks do not require investment in hard infrastructures, nor do they involve demolishing buildings or undertaking massive development; they are in fact very low-tech urbanism. The city of Barcelona has been implementing Superblocks as one of the measures to combat climate change with very positive results. The paper analyzes the concept of the Superblock and its relation with climate change in cities. Along these lines, it analyzes the pioneer experience of Barcelona in the development and implementation of the Superblocks, as a radical plan aimed at taking back the streets from cars. The role of political power and institutional leadership has been key in societal acceptance and the achievement of tangible results. But there are also obstacles and drawbacks in the development of these types of Superblocks, such as the necessity to redesign the collective transport network so that car traffic can truly be reduced in cities, the possible negative influence on traffic going in and out of the city, the lack of visible advantages if they are not implemented in the entire city, the risk of gentrification in the areas with Superblocks, public opposition, and opposition from certain sectors of the business community.
\end{abstract}

Keywords: superblocks; climate change; cities; urban mobility; Barcelona

\section{Introduction}

Climate change is one of the major challenges faced by today's societies. The human cause of climate change is global warming produced by the greenhouse gas (GHG) effect emitted by manufacturing, consumption and other activities engaged in by our societies today, compounded by the climate's natural variability [1]. There is tremendous effort involved in not surpassing the $2{ }^{\circ} \mathrm{C}$ increase agreed upon-and ideally limiting it to $1.5^{\circ} \mathrm{C}$-by the UN in the Paris Agreement [2]. It is necessary to augment national contributions to lowering GHG, in accordance with the latest United 
Nations Conference of the Parties [3], held in 2019 in Madrid, Mitigation and Adaption to climate change are presented as instruments to attain these objectives [1,3].

Cities are closely linked to climate change. They are major contributors to this change, as they produce over 70 per cent of GHG emissions, and they are likewise vulnerable hotspots of climate change impacts [4]. However, at the same time, cities are key players in the fight against climate emergency [5].

Half of a city's GHG emissions are linked to transportation. Automobile use in cities produces primary polluting emissions ( $\left.\mathrm{CO}, \mathrm{SO}_{2}, \mathrm{NOx}, \mathrm{PM}\right)$ and secondary emissions (ozone, among others) [6], in addition to noise, traffic congestion, and public space occupation, in addition to other problems. Furthermore, $68 \%$ of the world population is projected to live in urban areas by the year 2050 [7] and the number of cars is predicted to double by 2040 [8]. All of this makes mobility in cities a key issue to consider in the fight against climate change, turning cities into agents for change toward a new mobility model that takes this phenomenon into account.

Today urban mobility largely reflects a city model that is dominated by mass use of the private automobile, and where collective transport is only a complementary means of mobility. The territorial development models and urbanism models of contemporary cities, with their corresponding mobility infrastructures, have principally responded to the needs of the private vehicle. One of the results of this focus has been urban air pollution, with negative consequences for human health and climate change [1].

Alternatives to this type of mobility in cities are being sought $[5,9,10]$, conceiving mobility of persons and goods in cities not only as an economic issue, but also considering urban dysfunctionalities in terms of the environment and quality of life.

However, the type of urban mobility is intrinsically linked with the type of urbanism and the city model. Extensive urbanization and functional separation, as theorized in the Charter of Athens [11], is very different from a compact city with a combination of uses, as is the Mediterranean city [12]. Both city types have very distinct mobility and urban infrastructures models, resulting in either opportunities or barriers to reducing private vehicle use in cities, and as such to combat climate change. In global terms, Salat et al [13] (p. 1) point out that "the challenge of a new science of cities is to understand the links between urban morphogenesis, efficiency and resilience" and all of that is related to climate change.

Furthermore, the type of urbanization, urban mobility, transportation and its corresponding infrastructures facilitate or not measures for mitigating and adapting to climate change [14].

The responses, in addition to the fight against climate change, have the potential to change the city model from that of dirty cities, subject to a high degree of pollution, noise, traffic congestion, to ones that are decarbonized, healthy, and sustainable [10].

This paper is placed within this context, analyzing the Superblocks, a proposal for urban physical infrastructure as one of the instruments in the fight against climate change. It deals with the concept of the Superblock as a new model of mobility that restructures the typical urban road network, which provides solutions to the main problems of urban mobility and improves both the availability and quality of the public space for pedestrian traffic results in decreased traffic, and as such lower emissions of greenhouse gases. In order to achieve these goals for a new model of mobility, two fundamental changes must be made: modification of the basic road network and the establishment of differentiated routes for each mode of transport [15].

This paper first analyzes the theoretical framework of the Superblock concept as an urban physical infrastructure and its connection with urban policies in the fight against climate change. Then it specifically analyzes one of the pioneer experiences in its implementation in the city of Barcelona ("superilla" in the Catalan language). It further focuses on the actors that have intervened and on the social processes involved in the development of Superblocks, from the point of view of everyday politics, not often taken into account in the successful transformation of urban adaptation [16]. The analysis is 
aimed at critically identifying the barriers and opportunities arising from the implementation of the Superblocks as urban infrastructures that can be used by cities to fight against climate change.

\section{Theoretical Framework: The Superblock Concept and the Change in the City Model}

The Superblock concept is not new. With different objectives, although always geared toward the search for "human" urbanism, there is a relevant corpus of empirical experiences with diverse results [17]. Numerous towns and cities around the world have implemented areas with elements based on living streets and shared space, or banned cars from their center.

Some of the experiences include the 'woonerf' [18] in the Netherlands, the 'home-zones' and 'share-spaces' in the UK [19] the 'micro-districts' in Russia [20], and the 'Superblocks' in China [21]. The Superblocks implemented in Barcelona have features that differ from these experiences. The main difference is that these types of Superblocks are contemplated for the urban design of the entire city. The aim is the reorganization of neighborhoods not only through streets, but also using the intersections of the blocks to redesign the use of public and private space, and the importance given to public participation in these spaces. The Superblocks in China differ also greatly from these studied in our paper because of their large size, both in total area and height, as well as their outside enclosure. At present, they are coming under criticism for diverse reasons [21,22]. In any case, these differences are related to the historic origin of these experiences and to cultural differences [22,23].

Regarding the specific connection between urban planning and climate change, the experience of Germany is relevant because it entails the legal foundations for spatial planning of general climate protection at the regional level. In their analysis on this experience, Wender et al. [24] point out that creating compact urban structures is one of the key factors for climate change mitigation, and the importance of the links between building stock density and transport. However, they recognized that comprehensive applied planning guidelines for climate protection still needs to be developed.

For the case of Barcelona, its antecedents can be found towards the end of the 19th century in the Plan Cerdá for the modern amplification of the city and the Plan Maciá of 1932, which although not fully implemented, laid the urban foundations for development of the present Superblocks.

The concept of Superblock in Barcelona is broad and within the framework of ecosystem urban planning [22], which targets a reworking of the city model with new uses of space, a higher percentage of green areas, reduced road network, and human and social biodiversity and complexity that guarantee social cohesion, with an efficient urban metabolism for the material flow of water and energy.

In this paper, the concept of Superblock is confined only to the issue of how to tackle the dysfunctionality of contemporary urban mobility in big cities, specifically in relation to GHG, human causes of climate change, which connects physical urbanism and functional urbanism.

Salvador Rueda [15] conceptualized the Superblock as "a new model of mobility that restructures the typical urban road network. In physical terms, the Superblocks are made up of a grid of basic roads forming a polygon, approximately 400 by $400 \mathrm{~m}$, with both interior and exterior components and around 5000-6000 inhabitants per Superblock. The interior (intervia) is closed to motorized vehicles and above ground parking, and gives preference to pedestrian traffic in the public space. Though the inner streets are generally reserved for pedestrians they can be used by residential traffic, services, emergency vehicles, and loading/unloading vehicles under special circumstances. The perimeter, or exterior, of Superblocks is where motorized traffic circulates, and makes up the basic roads". Figure 1 illustrates the differences in use between the dominant model of urban mobility of single use and that of the multiple uses and functions of Superblocks. 


\section{SUPERBLOCKS MODEL}

\section{Current Model}

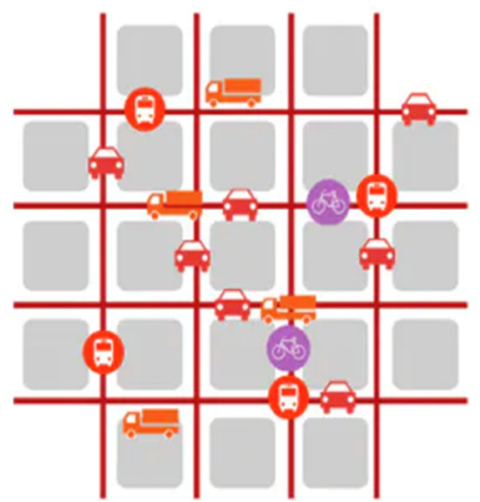

Superblocks Model

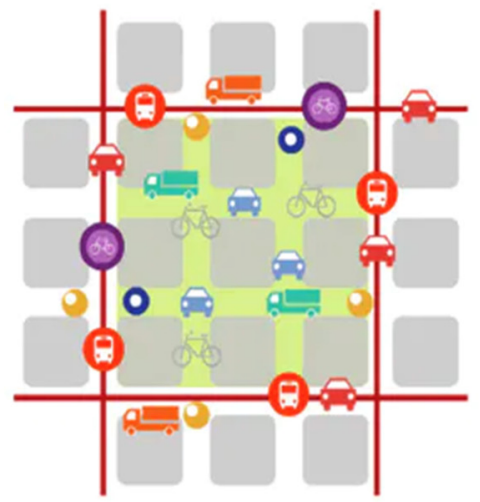

PUBLIC TRANSPORT NETWORK

Figure 1. Differences between the single use model of urban mobility and the Superblock model.

Source: Reproduced from [15].

As such, there will barely be any traffic inside the Superblocks, which makes streets much more accessible for pedestrians. Accordingly, Superblocks provide solutions to the main problems of urban mobility and improve both the availability and quality of the public space for pedestrian traffic.

What does the model based on a change in design of urban infrastructures offer? By reducing private vehicle traffic, (i) it increases space for pedestrians and accessibility, (ii) improves air quality, (iii) and reduces noise (Figure 2). The result is an increase in public space, safer zones for children and seniors, an increase in green areas, an expansion in the economic activity of small businesses, and viable alternatives to motorized mobility [15].

\section{Current situation}
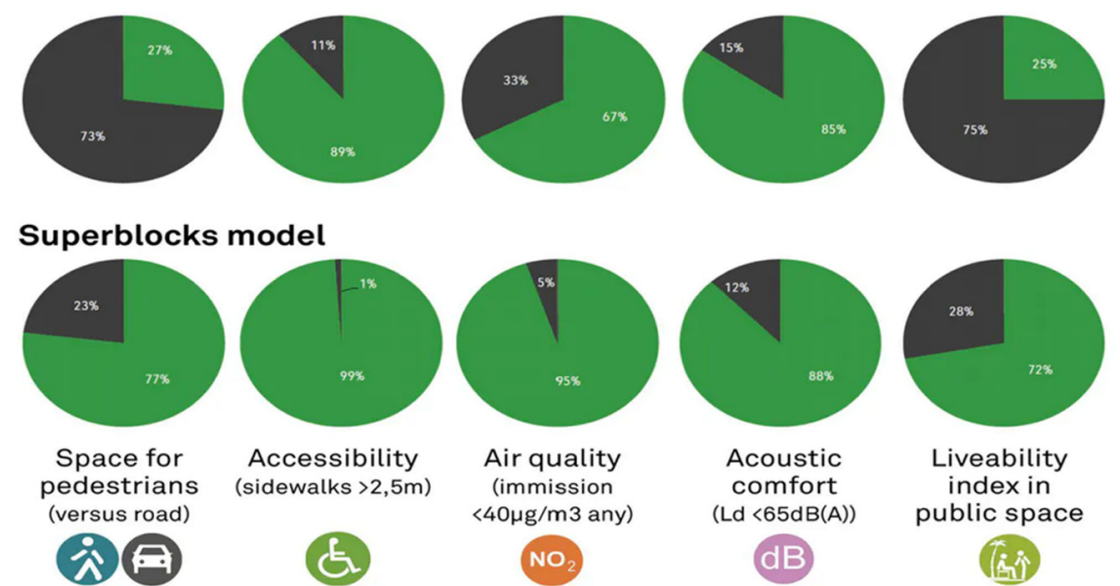

$\mathrm{NO}_{2}$

dB

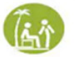

Figure 2. Space for pedestrians, Accessibility, Air quality, Acoustic comfort, Livability Index in public space. Current situation. Superblocks model. Barcelona. Source: Reproduced from [25].

The economic effects of transforming the existing urban blocks are also striking. For Barcelona, according to Love \& Stevenson [26], it results in saving of $€ 1.7$ billion ( $\$ 2.7$ billion) a year. This benefit 
mainly comes from increased life expectancy, a $20 \%$ reduction in premature mortality and a $13 \%$ reduction in the overall burden of illness and disease.

Moreover, the implementation of the present Superblocks does not require investment in hard infrastructures, tearing down buildings or undertaking massive redevelopment. A change in the use of already existing structures is sufficient-blocks-which only requires a functional change that completely modifies the city mobility structures, resulting in a reduction of urban traffic and GHG emission. It is very low-tech and low-cost urbanism [15,27].

The ecological crisis has propelled the design of models for eco-cities. However, the difference between the two models is that the Superblocks put human beings at the heart of the urban ecosystem and emphasize the importance of citizens' relationships with each other and the city itself [28,29]. In addition, the urban model of Superblocks is characterized by its scalability so that it can be applied to new urban developments as well as to the regeneration of suburbs and city centers.

Undoubtedly making part of a city into pedestrian spaces in order to reduce private vehicles by at least a third requires a strong network of public transport instead of the current radial network, so as to increase connectivity and achieve optimization similar to that of the metro.

Furthermore, the advantage offered by the Superblocks is creation of not only micro neighborhoods, but of an ideal structure for development of a collective transport system for the entire city, with an orthogonal system of buses to substitute the radial model existing in many cities. Barcelona has a network of buses based on a radial scheme, inheriting to a large extent the tracks of the old streetcars. The radial transport systems are much slower for getting around, with a greater cost in time and in distance. In contrast, an orthogonal system allows increased use of collective transport, with interconnectivity through horizontal and vertical lines that constitute an urban network structure (Figure 3).

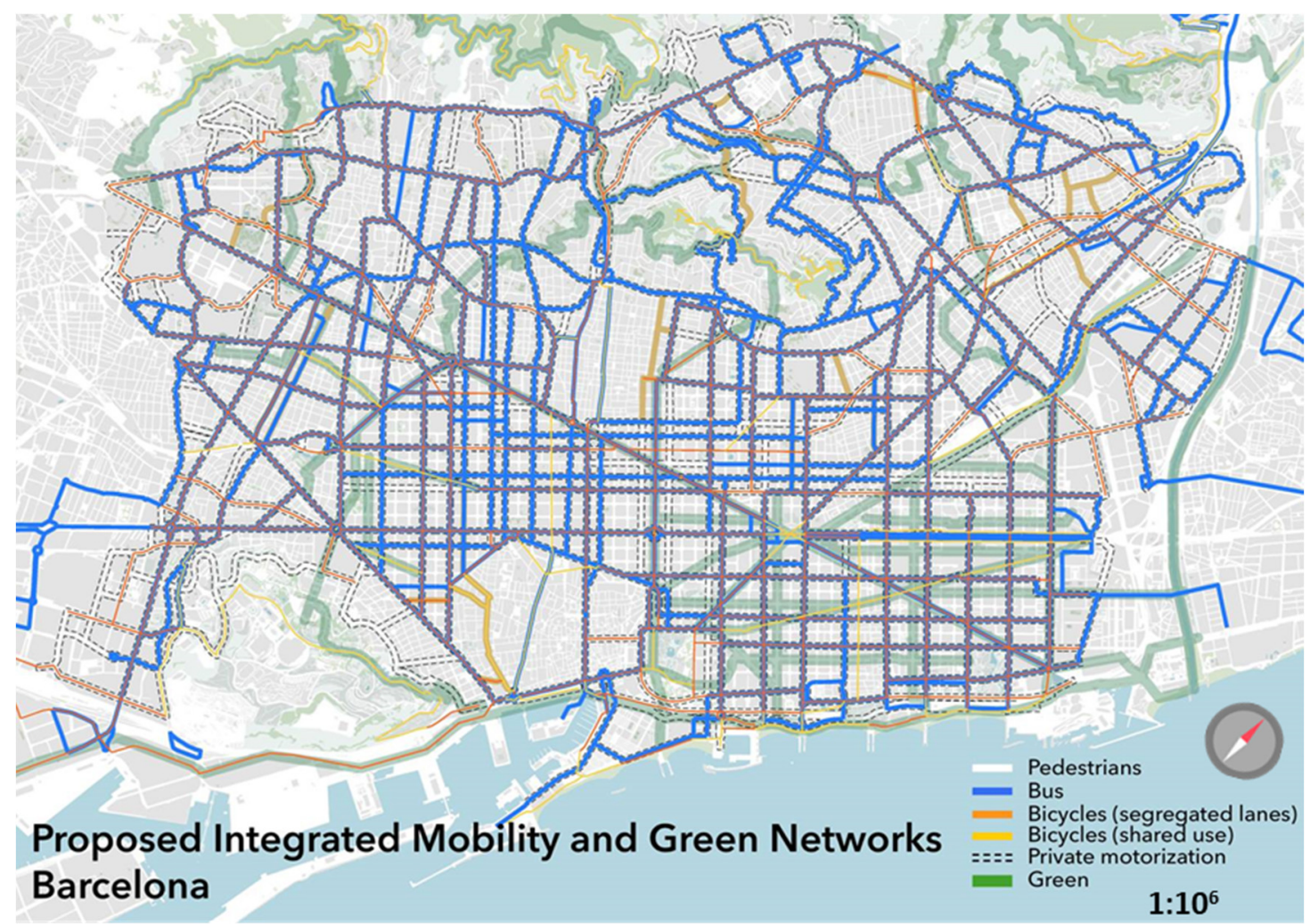

Figure 3. Proposed Integrated Mobility and Green Networks. Barcelona. Source: Reproduced from [30].

An orthogonal model increases the frequency of public transportation (one bus instead of several per bus stop, at a frequency of $3-5 \mathrm{~min}$ ) and brings about a greater connectivity for the city 
than the model for private vehicles [30]. Its objective is to absorb the cars that have been pushed out by pedestrianization with the Superblocks with an efficient, effective and equitable collective transportation system.

Thus a symbiosis is produced between the Superblocks and the orthogonal network of motorized mobility, which results in a decrease in the GHG produced by the intense traffic of private vehicles [30]. Accordingly, Superblocks are infrastructures useful for mitigating climate change. In addition, they lead to an increase in the green spaces inside them by freeing up public space used by cars. This vegetation then becomes a tool to adapt to climate change by facilitating the lowering of the temperature in the "heat island" phenomena of cities [31]. Mitigation and adaptation are two key instruments in the fight against climate change [1,24].

The Superblock is one of the main technical instruments of urbanism with an ecosystemic approach [28], which is necessary to take on the problem of climate change. Furthermore, it enables achievement of the Sustainable Development Goals proposed by the United Nations in Agenda 2030, which Spain joined [32].

"The Superblock model also works towards achieving the ambitious targets set by the Sustainable Development Goals (SDGs) that define sustainable city and community development in SDG 11 as a pressing issue and leverage point to overcome global challenges related to poverty, inequality, climate, environmental degradation, prosperity, peace, and justice" [33] (p. 2).

Superblocks are currently constructed or approved for construction in several, topologically diverse, Spanish cities and other cities in the world. In Spain, the city of Vitoria-Gasteiz was the winner of the European Green Capital Prize 2012, and the Plan for Mobility and Public Space has been rated Best Practice by Un-Habitat. The Superblock of Gràcia (Barcelona) was awarded first prize for its innovation by BMW in 2011 and was recognized as a sustainable Best Practice by Un-Habitat in 2010.

\section{Method}

The methodology for our analysis follows the proposed objectives of examining the experience of the Superblocks in Barcelona, geared toward reducing traffic and consequently GHG emissions as well as improving the urban climate, focusing on their potential as well as on the political, social and cultural barriers to their implementation. The most appropriate methodology for analyzing these objectives is qualitative case study [34].

In order to identify and critically analyze both their potential and the barriers faced we first elaborate on the concept of Superblock, and then the situation of its implementation and development in the city of Barcelona through the city government's plans and proposals. Finally the analysis focuses on the political and social actors based on the literature, the news in relevant local and international newspapers, City Council documents, and documents and interviews with the Urban Ecology Agency of Barcelona (Agencia de Ecología Urbana de Barcelona), which has been a key actor since the beginning of the Superblocks. The following are the methods according to the objectives:

Objective 1: To elaborate on the concept of the Superblock and its implementation in Barcelona.

Method: Literature review, analysis of the City Council official documents and plans (The Urban Mobility Plan for 2013-2918; The New Mobility Plan for 2019-2024; Barcelona's Commitment to Climate; Green and Biodiversity Plan of Barcelona 2020; Citizen Commitment to Sustainability 2012-2022; Superblocks Let's Fill the Streets with Life program), analysis of the documents elaborated by the Urban Ecology Agency of Barcelona (Conceptual Model), and interviews to both institutions.

Objective 2: The political and social actors.

- Method: Content analysis [34] (more content for or against) of the news related to the Superblocks of Barcelona in local newspapers (from 1 January 1990 to the present; search 'superilles') 
La Vanguardia [35], El Periódico [36], and in international newspapers; search 'superblock' (The New York Times [37], and The Guardian [38], the official documents from the City Council, and interviews with the Urban Ecology Agency of Barcelona.

\section{The Superblocks Program in the City of Barcelona}

Barcelona is located in the northeastern part of Spain (Figure 4). It is a densely populated city, with more than 1.6 million people per $100 \mathrm{~km}^{2}$, one of the highest population densities in Europe. It is the sixth largest city, population-wise, in the European Union, and its metropolitan area is home to more than 5 million inhabitants.

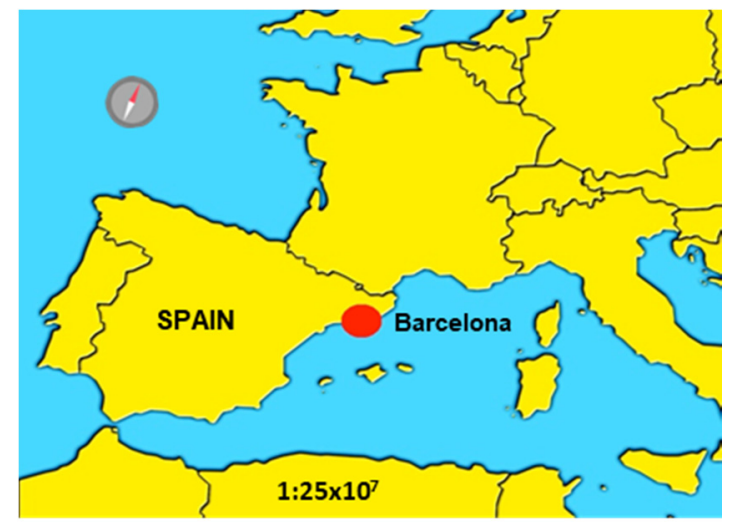

Figure 4. Barcelona's location, latitude 41.3887901 and longitude 2.1589899.

Barcelona is a global city, of great cultural, financial, commercial, and touristic importance. It is a vital communication point between Spain and France and it also has one of the chief ports in the Mediterranean.

However, the city of Barcelona has some of the highest levels of air pollution in Spain, which surpass recommendations from the World Health Organization (WHO) [39] (Figure 5). Sixty percent of the city's public space is dedicated solely to motor vehicles and to functioning as thoroughfares for vehicles in the metropolitan area [40].

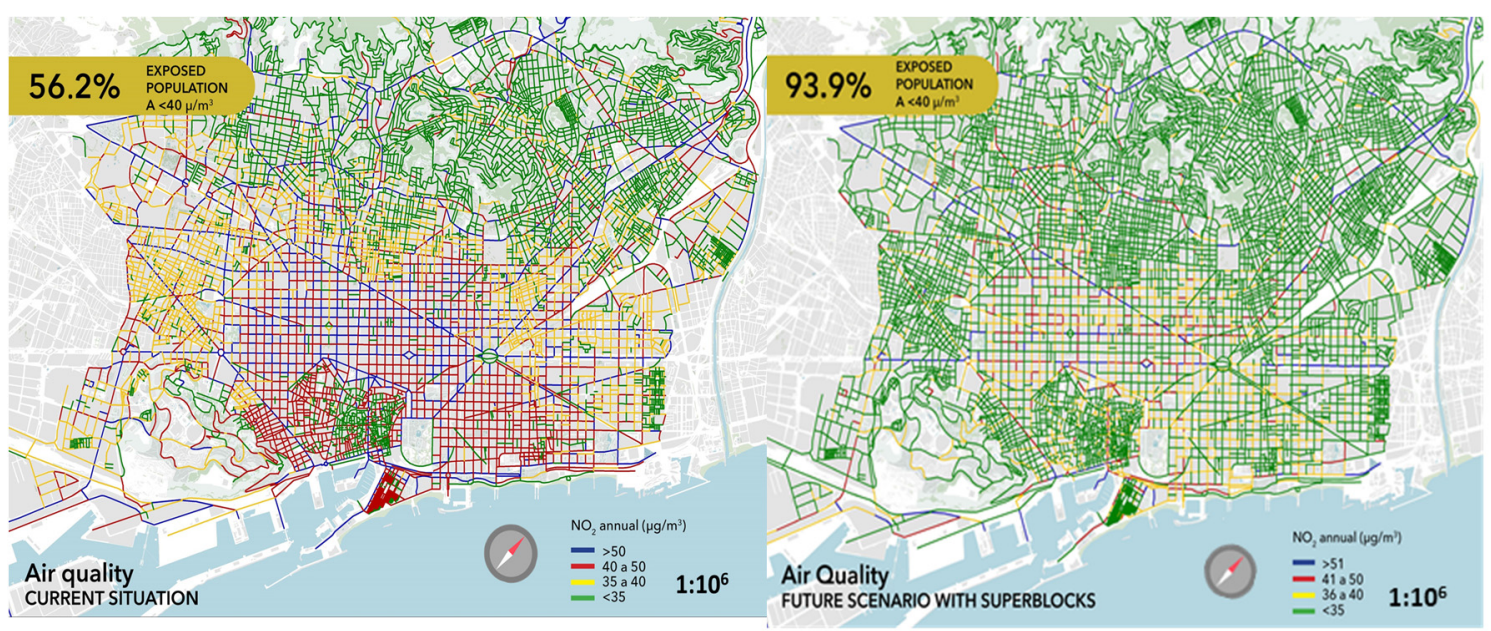

Figure 5. Population exposed to air quality, current situation and future scenario with Superblocks. Barcelona. Source: Reproduced from [25].

Additionally, the city of Barcelona is exposed to heat waves, which are increasing in frequency and intensity due to climate change and which aggravate the urban "heat island" phenomenon. The temperature in the city center of Barcelona can sometimes surpass the temperature in its periphery 
by as much as $7.5^{\circ} \mathrm{C}\left(45.5^{\circ} \mathrm{F}\right)$ [31]. This heat island in Barcelona, linked to global warming, poses a new risk for human health in the city center linked to global warming.

Faced with this situation, the city of Barcelona has established the goal of diminishing $\mathrm{CO}_{2}$ emissions by $40 \%$ to 2030 compared to 2005 levels, which is a mitigation measure for climate change, as well as increasing by $1.6 \mathrm{~km}^{2}$, that is $1 \mathrm{~m}^{2}$ per current inhabitant, the green urban spaces, which is a measure for adaption to climate change [40].

As for automobile traffic, the principal cause of GHG in the city, the new Urban Mobility Plan (2019-2024) [41] foresees that the amount of traffic can be reduced by $21 \%$ after the Superblocks are implemented. In absolute values it is supposed to go from 785 tons of $\mathrm{CO}_{2}$ to 608 tons (reduction of 177 tons). By closing down a good number of public roads to normal traffic there will also be 160 new squares in the city which will all have to be given a new function. Many of these squares will be transformed into green parks to improve the air quality of Barcelona. Such an increase in green space within the city's urban areas combined with the reduced number of cars will have a very significant impact on Barcelona air quality.

Within this context, the Barcelona City Council has to date developed six Superblocks (Table 1) and begun the process of three new superblocks, through the program "Llenemos de vida las calles. La implantación de las supermanzanas en Barcelona" [42] (Let's fill the streets with life! Implementation of Superblocks in Barcelona). The concept of Superblocks was adopted as a centerpiece of the city's mobility plan in 2015, promoted by Salvador Rueda, director of the Urban Ecology Agency of Barcelona.

Table 1. Current Superblocks and features. Barcelona.

\begin{tabular}{cccccc}
\hline Neighborhood & $\begin{array}{c}\text { Population } \\
\text { (2019) }\end{array}$ & Ha. & Year Approved & $\begin{array}{c}\text { Governing Political Party } \\
\text { Orientation }\end{array}$ & $\begin{array}{c}\text { Civil Society } \\
\text { Opposition }\end{array}$ \\
\hline La Ribera (Born) & 5993 & 12.48 & 1993 & $\begin{array}{c}\text { Coalition: social democrat, } \\
\text { left, pro-independence }\end{array}$ & No \\
\hline Gracia & 18,631 & 22.96 & 2003 & The same coalition & Yes/No \\
\hline Poblanou & 1486 & 16 & 2016 & $\begin{array}{c}\text { Coalition: left, social } \\
\text { democrat }\end{array}$ & Yes \\
\hline San Antoni & 38,566 & 48.81 & 2018 & Left & No \\
\hline Les Corts & 11,049 & 21 & 2018 & Center pro-independence, \\
left & No \\
\hline Hortafrancs & 8555 & 22.63 & 2018 & $\begin{array}{c}\text { Center pro-indipendence, } \\
\text { left }\end{array}$ & No \\
\hline
\end{tabular}

Source: Authors based on the interview with BCNEcologia.

This program is an instrument for reorganizing the city so that pedestrians have priority, followed by bicycles, and then public transport. The main goals are to improve the environmental conditions in the city and gain quality public space for persons [42]. So far, it has been implemented in six neighborhoods, but the aim of the city government is to develop Superblocks in all of the city-more than 503 Superblocks over time-with two levels of actions: at the district level and at the neighborhood level. By 2023 there could be 18 Superblocks distributed throughout the city.

Today, $85 \%$ of the transportation network in Barcelona is taken up by use related to transit mobility. The global proposal for Superblocks for the whole city represents a $61 \%$ reduction in thoroughfares for automobiles (Figure 6), as well as an orthogonal model for a mesh network of buses for public transport (Figure 3). 

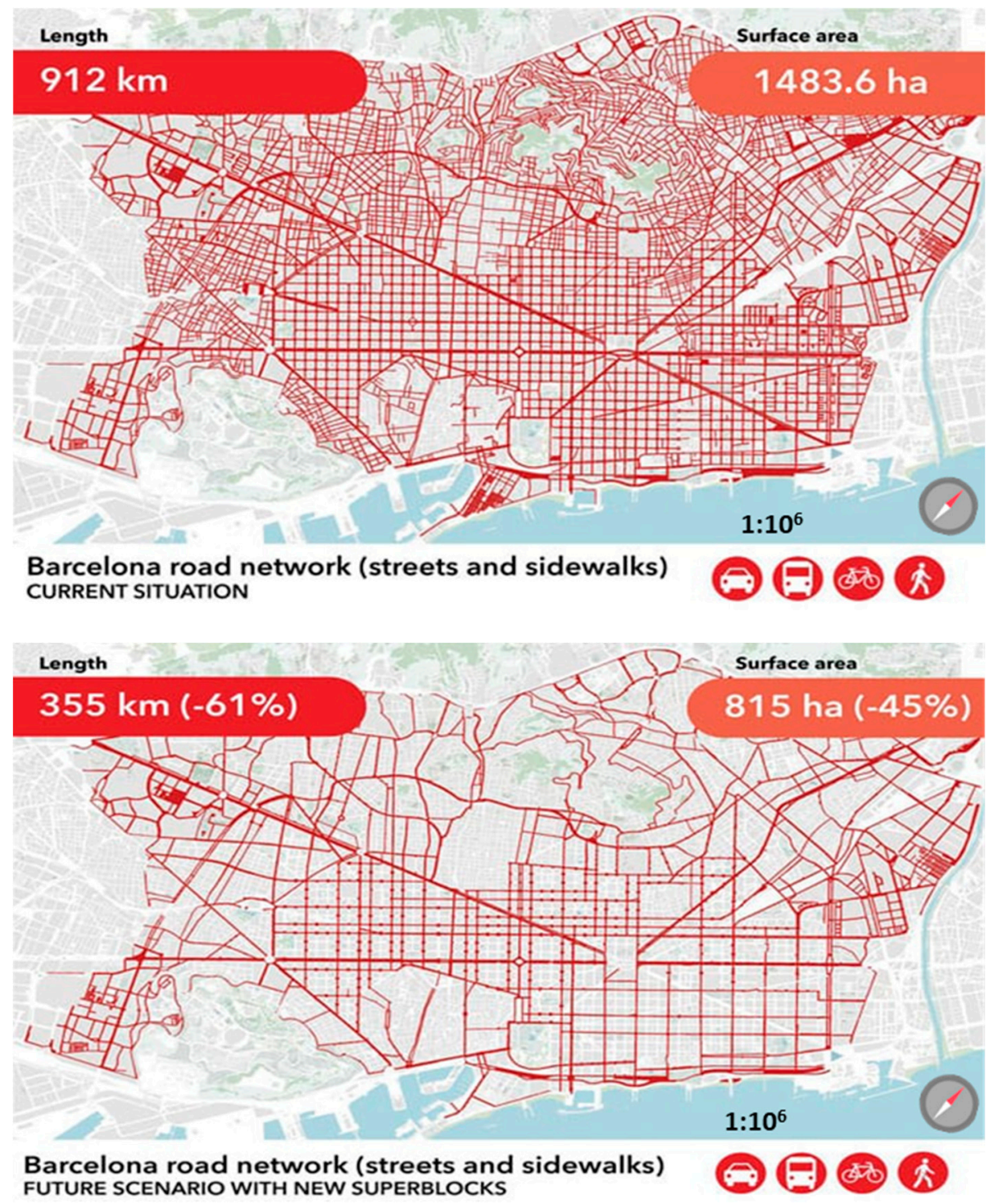

Figure 6. Barcelona road network, current situation and future scenario with new Superblocks. Source: Reproduced from [15].

Seventy percent of the urban mobility space taken up by cars will be freed up, just by reducing by the number of cars in circulation by $13 \%$. This represents a total of more than six million square meters, thereby converting Barcelona into the most important urban recycling project worldwide without involving demolition of buildings. This new model enables travel time in the city to be cut in half and increases the use of buses as mass transport, which could substitute from one third to more than one half of the current use of cars. For this purpose, additional measures are necessary: increasing the number of bus lanes, and bike and scooter paths, among others [15].

Moreover, pedestrianizing the Barcelona Superblocks has increased the pedestrian space to $67.2 \%$ so far, and will achieve a total increase of $270 \%$ once the total number of Superblocks is implemented (Figure 7). 


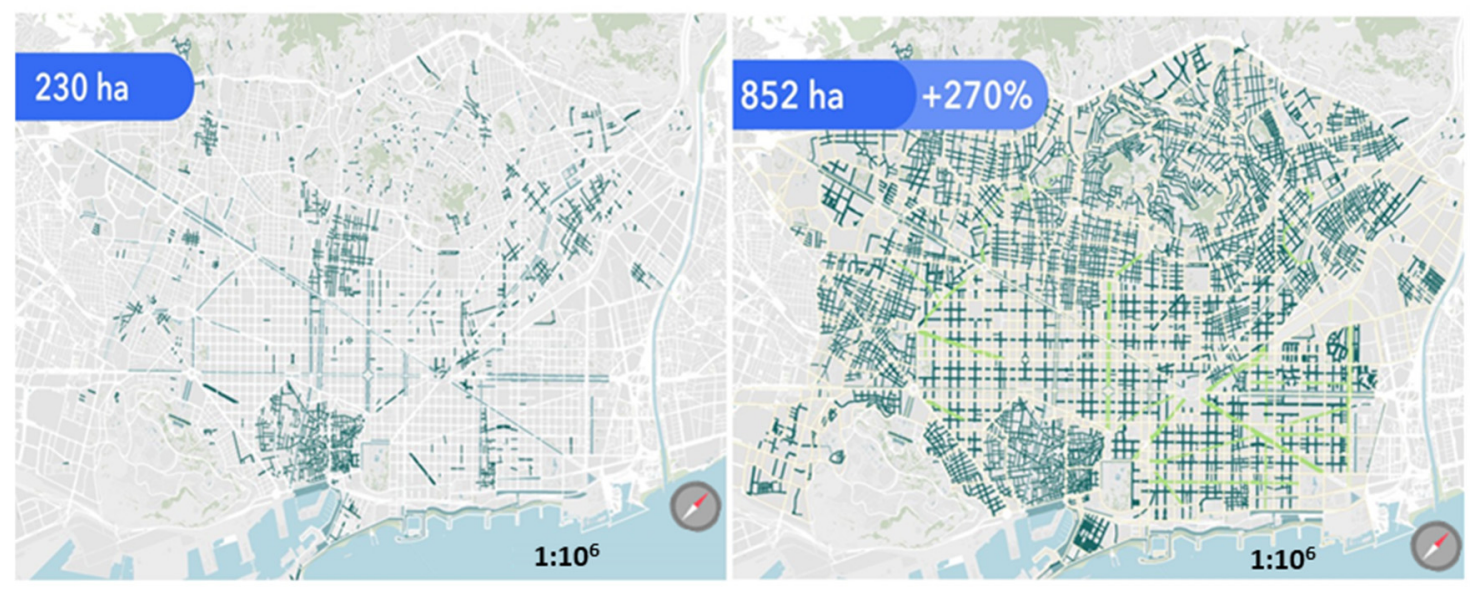

Figure 7. Pedestrian space in Barcelona before and after Superblocks. Source: Reproduced from [15].

The completed implementation of the Superblocks would reduce average annual levels of ambient $\mathrm{NO}_{2}$ pollution by $24 \%$ (from the current level of $47 \mu \mathrm{g} / \mathrm{m}^{3}$ to $36 \mu \mathrm{g} / \mathrm{m}^{3}$ ), a decrease that would bring Barcelona's levels in line with the WHO: a maximum of $40 \mu \mathrm{g} / \mathrm{m}^{3}$ [30], cutting down $\mathrm{CO}_{2}$ emissions per capita by $40 \%$.

For Salvador Rueda [15] and Mueller et al. [33], (p. 2) the "Barcelona Superblock model is an innovative urban and transport planning strategy that aims to reclaim public space for people, reduce motorized transport, promote sustainable mobility and active lifestyles, provide urban greening and mitigate effects of climate change".

To this it must be added that on 1 January 2020, the municipal government declared a climate emergency in the city, and to confront this situation, the City Council activated a set of urgent measures agreed on at its first Climate Emergency Committee, in which more than 200 entities, experts and administration representatives take part. Within the Climate Emergency Action Plan a broad range of measures related to mobility and renewable energy are included, among others [43], as well as indications on how to start up new Superblocks.

At this moment in the process of developing Superblocks, some warnings are being sounded. The Barcelona Laboratory for Urban Environmental Justice and Sustainability [44] points out the risk of gentrification and the scant consideration given to the social dimensions of adaptation to urban climate change in relation to matters of equality and justice. These authors call for the need to integrate such issues into the planning and development processes for these urban infrastructures.

The history of the development of Superblocks in Barcelona began as a way to combat the intense noise from urban traffic hence environmental concerns related to traffic have been at the forefront. But the aim of sustainable development for the city must also take into account matters of social inequality that includes the "triple bottom line" approach.

\section{The Political and Social Actors: The Need for a Cultural Change}

Superblocks in a city as large and complex as Barcelona are not achieved quickly and without controversy or social conflict. They are a long-haul model and are carried out gradually over time and space, according to chiefly political and social possibilities, as they do not require substantial economic investments.

However, the change in a city's mobility that the development of the Superblocks entails is not a project that is easily carried out. It does not involve tearing down a city's historic walls for its modern expansion, but instead entails a different type of demolition: that of walls in the mind, that of mental "infrastructures" [45], which are more difficult to modify. Mobility in contemporary cities, closely linked to the car, is profoundly rooted in people's mind and daily habits. Therefore, this change must be understood as an everyday social experience, and not only as a set of economic and institutional 
processes. This dimension is, nonetheless, much less analyzed or considered in the development of Superblocks, in addition to the analysis of the processes of social and political conflict [16].

As an urban model, the first actor was the architect Cerdá. His initial plan for expansion of the city of Barcelona at the end of the 19th century established the bases for the modern blocks extending the city. This later facilitated development of the Superblocks toward the end of the 1980's, based on a noise map of the city undertaken by the Barcelona City Council. Using this diagnostic tool, an action plan was proposed to reduce noise, with one of the solutions being streets closed to automobile traffic. Although the original purpose was to combat the city's significant level of noise, afterwards, it was broadened to include improving air quality, as pointed out by Mueller et al. [33].

During these beginnings as well as in the later development, the City Council has been a key agent in the development of the Superblocks in Barcelona $[16,46]$ together with its promoter, Salvador Rueda, director of the Urban Ecology Agency of Barcelona. The diverse municipal governments, with their ideological differences and interests, have been the main protagonists [16,46]. However, the civil society of Barcelona is very diverse and active, so the complex interactions between the municipal government and the civil sector, including, for example, car industry lobbies, can help to explain the progress as well as the setbacks in the development process for Superblocks in Barcelona [16,40].

The Superblock project has been on the desk of municipal governments for some 20 years, with processes to support or to abandon the project, depending on the interests of the different parties governing the city. However it is not in fact differences in political ideology that explain the process, but rather other matters such as the dominant role of the car in the city or the lack of vision as to the importance of the Superblocks. Only recently is the focus of city administration and management being placed on sustainability [40,41], taking into account, not only economic issues, the entrepreneurial city, but also social, and environmental ones, which are referred to as the "triple bottom line" approach.

In recent city governments, the divide was due to which political party was given credit for its impetus and development. This is an indicator of the political importance that the development of the Barcelona Superblocks have acquired, in the context of the new paradigm of sustainable cities, articulated by the United Nations new urban agenda (UN, 2016) and also for the recognition of the experience of the Superblocks in Barcelona by the media. Today, the implementing actor of the superblocks is the city's current minority municipal government led by Barcelona en Comú (BeC), a new left-leaning political party [16,40]. Zografos et al. [16] (p. 9) in their analysis of the conflictive nature surrounding one of the Superblocks-Poblenou - find that "underlying drivers of barriers are to be found in political struggles for authority".

The mass media has also been an important actor, with the local press at first opposing the Superblocks, and the international press in favor. As Klause [46] (p. 1) points out in the analysis of the opposition to the Superblock pilot project-Poblenou-“local media coverage is more about implementation problems, opposition to the pilot-project and its alleged negative impact on the economy rather than about the potential benefits to public health, air quality or climate change mitigation". In this sense, the local media has lacked the necessary innovative vision required by a global city such as Barcelona. However, the coverage of the Barcelona Superblocks in such prestigious newspapers as the New York Times, considering its replicability in New York, and the Guardian greatly boosted local recognition.

As for the citizen as social actor, the response to the Superblocks has been diverse, ranging from initial strong opposition with later acceptance because of positive results (the case of the Vila de Gràcia Superblock in 2006 and The Poblenou), to other experiences of citizen support from the beginning (the La Ribera Superblock, in the old market of Born in 2012). In the case of Poblenou [16] (p. 1), the Plataforma d'Afectats per la Superilla de PobleNou (Plattform of people affected by the Superblock of PobleNou) have voiced "fierce opposition". They protested about the removal and relocation of bus stops, inadequate community consultation and higher traffic volumes along the exterior perimeter of the Superblock. 
In 2006, two Superblocks were established in Vila de Gràcia. There likewise was a great deal of opposition at the start (the 150 meetings, with 85 of them held at night, led to eventual acceptance of the initial proposal).

As pointed out by Welzer [45] (p. 32) "the infrastructures that owe their existence to the car not only form a part of our consciousness, but so also our standards of conduct, our ways of life. The superblock project itself that clashes with old established beliefs and habits and thus provokes social, cognitive and cultural contestation". Its generalized implementation requires a change of mobility habits in the city and a shared extra effort.

The Superblocks have been endowed with specific content in each ambit by the neighbors themselves, through participative processes designed to define the problems or the challenges together, and to jointly find solutions. A Superblock steering group is set up in each district where the program is being implemented, consisting of a group of people and/or representative bodies, to monitor the project. The group acts as a link between the technical team and residents, validating the different stages and helping to define the participation spaces, as well as the outcomes of the participation workshops and the technical work carried out. Public participation is present throughout the entire program, from initial diagnosis to implementing the planned actions.

These processes have been key to the progress, albeit somewhat slow, of the Superblock development in the city. Local acceptance of the Superblock has also grown over the years, although ongoing close collaboration with residents is essential to dispel fears. The active and diverse civil society in Barcelona has been a key agent in the implementation of the Superblocks in the city. In their analysis of the conflicts arising in relation to some of the Superblocks, Scudellari et al [47] point out that temporal synchronization between the urban level and the neighborhood level turns out to be particularly important to reduce conflicts and criticalities.

Cars always have long been correlated with modernity, for which the departure from the car-centric city will require a cultural change and shift of mindset, which can only happen over time [45]. Development of the current six Superblocks has taken over four decades. That may seem like too long of time, but we must take into account that a change in the mobility model of a city is underway. The climate emergency is driving the acceleration of this process of change.

On 1 January 2020 a climate emergency was declared by the City Council [43], and to deal with it, this coming autumn the municipal government will activate a set of urgent measures agreed upon by the first Climate Emergency Committee, in which more than 200 entities, experts and administration representatives take part. The action includes the areas of mobility, urbanism, education, energy and waste management, among others. Clearly, the policies to combat climate change require a collaborative government.

This new measure will undoubtedly allow the implementation of the Superblocks in Barcelona to progress since it includes finishing the third stage of the Sant Antoni I superblocks, the second stage of the Horta superblocks, drafting of the project of the Sant Gervasi-La Bonanova superblocks, the Izquierda de l'Eixample superblocks and the Derecha de l'Eixample superblocks, and initiating the participative processes for new Superblocks.

It is a long-haul model that is being made reality through gradual and shared implementation throughout the entire city. This generalized execution requires a change of habits in city mobility, a cultural shift and an additional shared effort. It is an open model and a collective transformation.

Political initiative is key for propelling the development of the Superblocks. However, the narratives created at the start are fundamental for its evolution. Unfavorable narratives emerge in relation to the negative impact of limiting private traffic, or even to limiting freedom of circulation, among others. The positive experience in terms of quality of life brought about by the development of Superblocks is nevertheless breaking down the mental barriers in these narratives. Positive narratives are arising from the real life experience in these new contexts. What is more, at present Superblocks has become a positive identity "brand" for Barcelona [48]. The current municipal government 
that has promoted the Superblocks received majority support in the last municipal elections in the Superblock areas.

The need for structured engagement between city stakeholders (governance, policy-makers, planners, decision-makers) and the scientific community is long overdue, and urban climate science is required to provide the rigorous evidence base for urban policy-making [4]. It is an open model and a collective transformation as mobility is both spatial and political.

\section{Discussion and Conclusions}

As one of the responses to the challenges of climate change in the 21st century, the development of Superblocks in the cities is an imaginative and relatively simple one. If today the focus is on climate change, concerns are also arising from the effect on health as well as on extreme weather episodes, air quality, noise, traffic congestion, etc., brought about by motorized mobility in and outside the city (going into and out of the city).

There are clear opportunities and benefits from the Superblock as urban infrastructure in the fight against climate change regarding the reduction of traffic and consequently the greenhouse gas emissions along with freeing up space for green areas.

The fact that it is not necessary to implement major changes in urban planning, and that it is a multi-purpose and versatile instrument for different contexts whether they are new urban developments or regeneration of consolidated areas [49], makes the model of the Superblock an important tool for mobility, capable of improving the lives of people in cities of any type, and for climate change mitigation and adaptation.

Notwithstanding, Superblocks also present some barriers and possible negative effects that could limit their development and as such, their effectiveness in relation to climate change. In cities with not only local but also regional traffic, the implementation of Superblocks could lead to increased regional traffic congestion. In this sense, coordinated efforts between the various municipalities in the region are required. This is a political barrier that could hamper its development.

A conclusion in this respect is the importance of approaching the role of Superblocks in a comprehensive way within the framework of the ecosystem urban planning of cities. The experience of Barcelona shows that in order for Superblocks to obtain full efficiency in reducing private traffic, other complementary strategies need to be undertaken, such as design of public transportation in symbiosis with the design of Superblocks. If urban residents are to give up their cars, they need to be able to access the rest of the city. The partial understanding of Superblocks in and by themselves brings about improvements that can scarcely be seen by both the residents and the commuters. This is a social barrier to its rapid development. Superblocks make the most sense when they are extended all over the entire city in the form of a network. This involves going from managing mobility infrastructures to managing infrastructures with broader positive socioecological consequences.

The urban success of the Superblocks could also bring about a collateral effect of gentrification, if matters of social inequality and justice are not taken into account. To overcome this social barrier, its design and implementation needs to focus on sustainable development based on the three pillars of the triple bottom line. The potential for the Superblocks to improve the environment of cities, and specifically the urban climate, should not make us forget the Superblocks' goal of not producing greater social inequality.

Lessons can be learned with respect to these issues from Barcelona's superblock intervention, a transformational project that challenges the current model of urban development by employing radical changes in the urban infrastructure in order to mitigate carbon emissions and respond to climate-change induced problems like the urban heat island effect. Other similarly dense cities with mixed-use development can learn from Barcelona's Superblocks experiences, while adapting and modifying them to different historical and cultural contexts. The City Council, or the corresponding municipal government, is a key player in this process. Political conflicts at the municipal government level could be an obstacle to the change in the urban model required for the Superblocks. However, only through 
the interaction of urban climate science/policy makers/civil society is it possible to move forward in the implementation of the Superblocks as a tool to fight against climate change. Well-organized public participation processes are vital for the acceptance of the Superblocks projects.

Superblocks not only modify a city's physical and functional structures, but they also modify its mental barriers, which are based on car-centered city models. Cities needs to change their coordinates towards a low-carbon transition when the movement of people and things are major contributors to GHG. That makes it necessary for us to look at the past to imagine the future; it requires a present-the fight against climate change-with a historical awareness that also looks towards the future. This is key to fighting such a far-reaching problem, as is climate change.

Author Contributions: Conceptualization, I.L., J.O. and M.P.; methodology, I.L., J.O. and M.P.; research, J.O. and M.P.; writing — original draft preparation, I.L.; writing—review and editing, J.O. and M.P. All authors have read and agreed to the published version of the manuscript.

Funding: This research received no external funding.

Acknowledgments: The authors are grateful to the anonymous reviewers for their helpful suggestion on improving the text.

Conflicts of Interest: The authors declare no conflict of interest.

\section{References}

1. IPCC. Summary for Policymakers. In Climate Change 2014: Mitigation of Climate Change. Contribution of Working Group III to the Fifth Assessment Report of the Intergovernmental Panel on Climate Chang; Edenhofer, O., Pichs-Madruga, R., Sokona, Y., Farahani, E., Kadner, S., Seyboth, K., Adler, A., Baum, I., Brunner, S., Eickemeier, P., et al., Eds.; Cambridge University Press: Cambridge, UK; New York, NY, USA, 2014.

2. UN. Paris Agreement; United Nations: New York, USA, 2015. Available online: https://unfccc.int/sites/default/ files/english_paris_agreement.pdf (accessed on 22 November 2019).

3. UN. Chile-Madrid Time for Action; United Nations: New York, USA, 2019. Available online: https://unfccc.int/ sites/default/files/resource/cp2019_L10E_adv.pdf (accessed on 22 January 2020).

4. Cities IPCC. Global Research and Action Agenda on Cities and Climate Change Science; Cities IPCC: Geneve, Switzerland, 2018.

5. ICLEI. Resilient Cities Report 2017; ICLEI: Bonn, Germany, 2017. Available online: https://worldcongress2018. iclei.org/wp-content/uploads/Resilient-Cities-report-2017.pdf (accessed on 22 November 2019).

6. WBGU. Humanity on the Move: Unlocking the Transformative Power of Cities; German Advisory Council on Global Change, WBGU: Berlin, Germany, 2015.

7. UN. World Urbanization Prospects: The 2018 Revision; United Nations: New York, NY, USA, 2019.

8. World Economic Forum. 2016. Available online: https://www.weforum.org/agenda/2016/04/the-number-ofcars-worldwide-is-set-to-double-by-2040 (accessed on 22 November 2019).

9. WHO. Environmental Noise Guidelines for the European Region; WHO Regional Office for Europe: Copenhagen, Denmark, 2018.

10. GrowSmarter. Implementing Sustainable Urban Mobility in European Cities-Conclusions from GrowSmarter; GrowSmarter: Barcelona, Spain; Cologne, Germany; Stockholm, Sweden, 2019. Available online: https:// grow-smarter.eu/fileadmin/editor-upload/Reports/GrowSmarter_Concluding_Report_WP4.pdf (accessed on 22 November 2019).

11. Corbusier, L.; Eardley, A. The Athens Charter; Grossman Publishers: New York, NY, USA, 1973.

12. Leontidou, L. Mediterranean City. In The Wiley Blackwell Encyclopedia of Urban and Regional Studies; Wiley: Hoboken, NJ, USA, 1990; pp. 1-8.

13. Salat, S.; Bourdic, L.; Labbe, F. Breaking symmetries and emerging scaling urban structures: A morphological tale of 3 cities: Paris, New York and Barcelona. ArchNet-IJAR Int. J. Archit. Res. 2014, 8, 77. [CrossRef]

14. Bulkeley, H. Cities and Climate Change; Routledge: London, UK; New York, NY, USA, 2013.

15. BCNEcologia. Superblocks. Conceptual Model, 2018. Available online: http://www.bcnecologia.net/en/ conceptual-model/superblocks (accessed on 22 November 2019). 
16. Zografos, C.; Klause, K.A.; Connolly, J.J.; Anguelovski, I. The everyday politics of urban transformational adaptation: Struggles for authority and the Barcelona superblock project. Cities 2020, 99, 102613. [CrossRef]

17. Reinoso Bellido, R.; Abarca-Alvarez, F.J.; Osuna-Pérez, F. Superblocks. Resiliencia, capacidad de adaptación y resistencia a la obsolescencia. In Proceedings of the Paper to the Conference on Obsolescence and Renovation-20th Century Housing in the New Millennium, Seville, Spain, 14-15 December 2015.

18. Schepel, S. Woonerf Revisited. Delft as an Example. 2005. Available online: http://www.woonerfgoed.nl/int/ Childstreet_files/StevenSchepel.pdf (accessed on 2 March 2019).

19. Karndacharuk, A.; Wilson, D.J.; Dunn, R.C.M. Evaluating shared spaces: Methodological framework and performance index. Road Transp. Res. A J. Aust. N. Z. Res. Pract. 2013, 22, 52-61.

20. Kukina, I.V.; Fedchenko, I.G. Rethinking Evolution of Spatial Structure of Russian Microdistrict in the Post-Soviet Space. 2019. Available online: http://elib.sfu-kras.ru/bitstream/handle/2311/111698/29_Kukina\% 20I.V.\%2C\%20Fedchenko\%20I.G.pdf?sequence=1\&isAllowed=y (accessed on 2 March 2019).

21. Kan, H.Y.; Forsyth, A.; Rowe, P. Redesigning China's superblock neighbourhoods: Policies, opportunities and challenges. J. Urban Des. 2017, 22, 757-777. [CrossRef]

22. Monson, K. String block vs superblock patterns of dispersal in China. Archit. Des. 2008, 78, 46-53. [CrossRef]

23. Gajer, S. Deconstructing the Superblock: Universal Solutions vs. Cultural Specificity in Chinese Urban Planning. Ph.D. Thesis, Carleton University, Otawa, ON, Canada, 2015.

24. Wende, W.; Huelsmann, W.; Marty, M.; Penn-Bressel, G.; Bobylev, N. Climate protection and compact urban structures in spatial planning and local construction plans in Germany. Land Use Policy 2010, 27, 864-868. [CrossRef]

25. Barcelona City Council. Urban Mobility Plan of Barcelona 2013-2018. Available online: http://prod-mobilitat. s3.amazonaws.com/PMU_Sintesi_Angles.pdf (accessed on 22 November 2019).

26. Love, P.; Stevenson, M.; Superblocks are Transforming Barcelona. They might Work in Australian Cities too. The Conversation. 17 September 2019. Available online: https://theconversation.com/superblocks-aretransforming-barcelona-they-might-work-in-australian-cities-too-123354 (accessed on 22 November 2019).

27. Grass, K. Redesigning the Grid: Barcelona's Experiment with Superblocks, 18 December 2017. Available online: https://urbanland.uli.org/planning-design/barcelonas-experiment-superblocks/ (accessed on 22 November 2019).

28. Rueda, S. Ecosistemic Urbanism; BCNEcología: Barcelona, Spain, 2016.

29. Ehrmann, S. Here come the Superblocks. 22 August 2018. Available online: https://www.toposmagazine. com/superblock-barcelona/ (accessed on 22 November 2019).

30. BCNEcologia. Bases Per a La Implantació D'una Nova Xarxa de BUS Per Barcelona en el Marc d'un nou Model de Mobilitat. 2004. Available online: http://www.bcnecologia.net/sites/default/files/pdfs\%20generals/ Bases\%20nova\%20xarxa\%20bus\%20ortogonal_BCNecologia.pdf (accessed on 22 November 2019).

31. Martin-Vide, J.; Moreno-Garcia, M.C. Probability values for the intensity of Barcelona's urban heat island (Spain). Atmos. Res. 2020, 240, 104877. [CrossRef]

32. Spanish Government. Agenda 2030. Available online: https://www.agenda2030.gob.es/ (accessed on 22 November 2019).

33. Mueller, N.; Rojas-Rueda, D.; Khreis, H.; Cirach, M.; Andrés, D.; Ballester, J.; Bartoll, X.; Daher, C.; Deluca, A.; Echave, C.; et al. Changing the urban design of cities for health: The superblock model. Environ. Int. 2020, 134, 105132. [CrossRef] [PubMed]

34. Bennett, A.; Elman, C. Qualitative research: Recent developments in case study methods. Annu. Rev. Polit. Sci. 2006, 9, 455-476. [CrossRef]

35. La Vanguardia. Available online: https://www.lavanguardia.com/hemeroteca (accessed on 22 November 2019).

36. El Periódico. Available online: https://archivo.elperiodico.com/ (accessed on 22 November 2019).

37. The New York Times. Available online: https://www.nytimes.com/search?query=archives (accessed on 22 November 2019).

38. The Guardian. Available online: https://www.theguardian.com/international (accessed on 22 November 2019).

39. ASPB La Salut a Barcelona 2019. ASPB. 2019. Available online: https://www.aspb.cat/wp-content/uploads/ 2019/12/ASPB_salutbarcelona2018.pdf (accessed on 20 January 2020).

40. Barcelona+Sostenible. Compromís de Barcelona pel Clima. Barcelona City Council. 2015. Available online: https:/ajuntament.barcelona.cat/premsa/wp-content/uploads/2015/11/Compromis_Bcn_Clima.pdf (accessed on 20 January 2020). 
41. Barcelona City Council. Nuevo Plan de Movilidad Urbana 2019-2024. Available online: https://www. barcelona.cat/mobilitat/es/actualidad-y-recursos/nuevo-plan-de-movilidad-urbana-2019-2024 (accessed on 22 November 2019).

42. Barcelona City Council. Supermanzanas-“Llenamos de Vida las Calles”. Available online: https://ajuntament. barcelona.cat/ecologiaurbana/es/con-quien-lo-hacemos/participacion-ciudadana/supermanzanas (accessed on 22 November 2019).

43. Barcelona City Council. Plan de Acción de Emergencia Climática. 2020. Available online: https://www.barcelona.cat/infobarcelona/es/medidas-urgentes-para-hacer-frente-a-la-emergenciaclimatica-2_836826.html (accessed on 20 January 2020).

44. Barcelona Laboratory for Urban Environmental Justice and Sustainability. Available online: http://www. bcnuej.org/outreach/barcelona-superblocks/ (accessed on 20 July 2019).

45. Welzer, H. Mental Infrastructures: How Growth Entered the World and Our Souls; Heinrich Böll Stiftung: Berlin, Germany, 2011.

46. Klause, K. Barcelona Superblocks: How Power And Politics Shape Transformational Adaptation. BCNUEJ. 6 April 2018. Available online: http://www.bcnuej.org/2018/04/06/barcelona-superblocks-how-socio-politicalpower-struggles-shape-transformational-adaption/ (accessed on 20 January 2020).

47. Scudellari, J.; Staricco, L.; Vitale Brovarone, E. Implementing the Supermanzana approach in Barcelona. Critical issues at local and urban level. J. Urban Des. 2019. [CrossRef]

48. Hu, W. What New York Can Learn from Barcelona's 'Superblocks', 30 September 2016. Available online: https://www.nytimes.com/2016/10/02/nyregion/what-new-york-can-learn-from-barcelonassuperblocks.html (accessed on 20 January 2020).

49. Rueda, S. Superblocks for the design of new cities and renovation of existing ones. Barcelona's case. In Integrating Human Health into Urban and Transport Planning; Nieuwenhuijsen, M., Khreis, H., Eds.; Springer International Publishing: Berlin/Heidelberg, Germany, 2019; pp. 135-154.

(C) 2020 by the authors. Licensee MDPI, Basel, Switzerland. This article is an open access article distributed under the terms and conditions of the Creative Commons Attribution (CC BY) license (http://creativecommons.org/licenses/by/4.0/). 